NBER WORKING PAPER SERIES

THE IMPORTANCE OF ECONOMIC

POLICY IN DEVELOPMENT:

CONTRASTS BETWEEN KOREA AND TURKEY

Anne 0. Krueger

Working Paper No. 2195

NATIONAL BUREAU OF ECONOMIC RESEARCH 1050 Massachusetts Avenue

Cambridge, MA 02138

March 1987

The research reported here is part of the NBER's research program in International studies. Any opinions expressed are those of the author and not those of the National Bureau of Economic Research. 
NBER Working Paper \#2195 March 1987

The Importance of Economic Policy in Development:
Contrasts between Korea and Turkey

\section{ABSTRACT}

In the mid-1950's, Turkey was a much richer country than Korea. With about the same population, Turkish GNP was about three times that of Korea, Turkish exports were fifteen times those of Korea, and the Turkish savings rate was much higher than Korean.

By 1980 , the situation was dramatically reversed, as Turkish income was 40 percent below Korea's, Turkish exports were less than onefourth those of Korea and the Turkish savings rate was about two-thirds of Korea's.

This paper examines the variables that affected economic growth and shows the critical importance of the different policy choices in the two countries.

Anne O. Krueger Department of Economics Duke University Durham, NC 27706 


\title{
THE IMPORTANCE OP ECONOMIC POLICY IN DEVELOPMENT: CONTRASTS BETWEEN ROREA AND TURKEY
}

\author{
Anne 0. Krueger*
}

In the early years of thinking about development, the majority of policy makers and development economists were skeptical -- to put it mildly -of the importance of the traditional "neoclassical" analysis and policy prescriptions. In no field was this more true than international trade, where doubts were expressed about the rate at which developing countries could expand their exports (elasticity pessimism), the probable future of terms of trade for primary commodities, and the ability of developing countries to experience satisfactory industrial growth in the absence of high walls of protection surrounding their infant industries.

Three phenomena proved that much of that skepticism was illfounded. First, empirical evidence failed to support either elasticity pessimism with regard to the terms of trade. Second, analytical developments revealed difficulties with a protectionist strategy even beyond those that had earlier been pointed out by advocates of free trade. Third, experience in developing countries that adopted protectionist strategies proved less satisfactory than had been anticipated, while those developing countries that adopted more outer-oriented trade strategies had performance that usually exceeded expectations.

* I am indebted to Bela Balassa, Vittorio Corbo, Kemal Dervis, Kwang Suh Kim, Chong Nam, Julio Nogues, Sarath Rajapatirana, and Rusdu Saracoglu for helpful comments on an earlier draft of this paper. 
Of the analytical developments that were important, development of the concept of effective protection was certainly key. In demonstrating that the same nominal tariff rate might imply very different rates of protection to value added for producers of different specific items, the concept served to underscore the infeasibility of a "rational" protective structure: the only uniform effective tariff was a uniform nominal tariff, which, in turn, implied a zero rate of protection or uniform nominal tariffs and export subsidies once it was recognized that tariffs did not affect the prices of exportables.

Max Corden's seminal work on effective protection was a key element in the gradual shift in thinking about trade policy in relation to development. His emphasis in both his teaching and research on the importance of trade policy, and his contributions to trade policy discussions, helped focus attention on the importance of these issues, and influenced both his colleagues and a generation of students. His careful, straightforward, analytical approach did much to clarify the issues and to speed the time when policies might shift.

Although good theory can inform policy decisions, it cannot by itself yield guidance as to the quantitative importance of those decisions. Moreover, most policies are implemented in an environment where myriad other changes are occurring simultaneously, and it is often difficult for the analyst, based on the experience of a single country, to infer the quantitative importance of a particular change. Hence, a variety of other methods of attempting to assess the quantitative importance of policy shifts are needed, none of which in and of themselves can prove conclusive but which, through the weight of cumulative evidence, can permit firmer judgments to form. 
One such method is comparison of countries with different policy regimes. An interesting one is that of Turkey and Korea, the subject of this essay. Both started out, in the 1950s, with a legacy of highly restrictive trade policies and severe macroeconomic imbalances. Turkey maintained a broadly restrictionist trade strategy until 1980, whereas Korea shifted in the early 1960s. While all countries have unique circumstances that make any comparison subject to numerous qualifications, the similarities and differences between these two countries make an interesting case study that demonstrate the importance of trade policy, and therefore of Corden's contributions, in the development process. An essay on the contrasts between Turkish and Korean experience therefore seems an appropriate tribute to him.

Out of this contrast, the lesson that "policies matter" emerges clearly. Any observer of developing countries in the 1950s would have concluded that, in almost all regards, Turkey had the more favorable development prospects. The Korean reforms of the early 1960s, however, led to a fundamental transformation of the economy. Although Turkey also undertook some necessary changes in policy in the late 1950s, the reforms centered only on immediate correction of macroeconomic imbalances, and did not encompass any overhaul of the incentive structure.

An initial section provides background information on the economic structures and other circumstances of the two countries in the early 1950s. A second section then traces the evolution of economic policy over the 1960-1985 period in the two countries. A final section then contrasts the economic performance of the two countries. 


\section{Initial Similarities and Differences}

\subsection{Pre-1953 Heritage}

Comparison of any two countries, especially with widely disparate cultural geopolitical backgrounds, is always hazardous. And, in some fundamental regards, the Turkish and Korean backgrounds are very different.

Although Turks were always a distinct group, Turkey was the seat of the Ottoman Empire until the first World War, and emerged thereafter as an independent Turkish nation under the leadership of Ataturk. ${ }^{1}$ Disassociation from the Ottoman rule brought with it the declaration that Turkey was a secular state, the introduction of Latin alphabet, and a conscious effort to "modernize" and adopt political, legal, and economic systems much more akin to those of Europe than to those associated with the Ottoman legacy. Nonetheless, the vast majority of Turks are Muslim and cultural ties to the Middle East remain. One might even venture the generalization that Turkey was and is caught between Europe and the Middle East and confronts a challenge to find her own unique identity between these two large and dissimilar regions. In the $1920 \mathrm{~s}$ and $1930 \mathrm{~s}$, many of the institutions that would be important in the postwar years were established. For present purposes, concern must be limited to noting those developments that significantly affected growth in the post-1950 period. After an initial period of relatively laissez-faire policies in the 1920 s and very low overall growth, the government rejected the philosophy and shifted to a policy of "Etatism" in the 1930s. Although "Etatism" as enunciated contained a large number of elements with important implications for policy (such as the view that there were no distinct economic interests and hence there was no recognition of any role or rights for particular groups such as unions or industrialists), the 
chief and lasting legacy was the establishment of a number of State Economic Enterprises (SEEs) which produced and marketed a variety of agricultural, mineral and manufactured commodities. Many of these SEEs produced manufactured goods that had previously been imported. High tariffs were established to protect the new enterprises. By the end of the 1940s, it is estimated that more than half of Turkish industrial production originated in SEEs. They produced, and continue to produce, a variety of import-substitute commodities, ranging from textile, clothing, and footwear to petroleum products, paper, fertilizer, and steel. In most activities, there is also private production.

The 1920 s and 1930 s also witnessed rapid expansion of Turkish schools, and an increase of educational attainments in Turkey. Even so, in 1950, about half of the male population over 14 years of age was illiterate.

Korea, by contrast, had a long history as a distinct nation prior to the 20th century, but was occupied as a Japanese colony in 1910. Korea is situated between the two geographic giants of East Asia - China and Japan just as Turkey is situated between Europe and the Middle East. Although there is a Confucian tradition in common with her Asian neighbors, Koreans have been a distinct ethnic group and nation for many centuries. They have tended to be somewhat inward-looking throughout their history, except when invaded or occupied by one of the two large Asian powers.

During the 1920s and 1930s, considerable manufacturing activity developed in Korea under Japanese occupation, although much of it was in the north and was owned by Japanese who also constituted a very high fraction (probably 80 percent) of the technical manpower. Under the Japanese, little emphasis was placed on educating Korean children, and such education as did 
occur was provided in. the Japanese language; use of Korean and teaching of Korean language and culture were forbidden.

During the Second World War, Turkey was not an active combatant, but nonetheless was largely cut off from international markets. Inflation rose sharply, reaching peak rates of 92 and 74 percent in 1942 and 1943 respectively (Hale, 1981, p. 69). Economic activity was stagnant due in large part to the cutoff from international trade. As of 1946, Turkey was the poorest country in Europe, with the lowest per capita income and the highest rate of inflation. It is estimated that real GNP in Turkey grew at an average annual rate of about 2 percent over the decade 1938 to 1948.

Whereas the Second World War was a period. of very slow growth for Turkey, it was a period of economic decline for Korea as the Japanese directed their efforts to the war. In 1945, the Japanese left and the country was partitioned along the 38th parallel: the south and north got approximately equal land (and arable land) areas, but the south got 17 million people, contrasted with the north's 8.8 million. The result was that there were only 1,309 square meters of arable land per capita in the South - the highest density of population in the world at that time. The Americans occupied what is now South Korea.

The north had been the source of most electric power and minerals, and a very high fraction of manufactured output of metal and chemical products, while the South had been predominant in textiles, processed foods, and machinery. The economic disruption after the war and partition, therefore, was probably as great, if not greater, than that of some of the countries in which fighting had occurred. For example, it is estimatd that, by 1948 , production of textiles was only about 18 percent of what it had been 
in 1939; machinery production stood at 40 percent of its 1939 level, and overall manufacturing production was about 14 percent of its 1939 level. (Frank, Kim and Westphal, 1975, p. 26.) The real economic dislocations were accompanied by a hyperinflation; the Seoul retail price index of 1949 was 123 times what it had been in June 1945 .

Thus, Korea's wartime legacy was vastly worse than Turkey's, although both countries had immediate reconstruction problems and low incomes. Both countries were recipients of sizeable amounts of foreign aid from the United States, starting in the immediate postwar years. But that is almost the only similarity, and even there, Korea received proportionately much more aid than Turkey. The events of the decade after the war ended in 1953 made the contrast much stronger, with everything apparently favoring rapid Turkish growth and hindering Korea's.

For Turkey, American aid under the Point Four Program and then the Marshall Plan was directed largely toward the development of infrastructure and agriculture. The government established very high support prices for agricultural commodities, and, in addition, a sizeable fraction of aid was allocated for the importation of tractors, and the conversion of pastureland and forests in the Anatolean plateau into wheat-growing areas. Wheat production boomed at a time when world prices were high and European demand was rising rapidly. By the early 1950s, Turkey was the largest exporter of wheat in the world, exporting a net of 600 thousand metric tons in 1953 and 950 thousand metric tons in 1954 (Krueger, 1974, p. 43) while simultaneously building up domestic stocks. ${ }^{2}$ The price supports translated rapidly into heavy budgetary costs, which were a major cause of inflationary pressure in the mid-1950s, but until 1953 were offset by Marshall Plan aid and export 
earnings at favorable terms of trade. It is estimated that Turkish real GNP at 1961 prices rose 15 percent of $1951,8.5$ percent in 1952 , and 11.2 percent in 1953 -- exceptionally rapid growth by any standard.

The Korean economy's evolution over the 1946-53 period falls into two parts. As already mentioned aid receipts were channeled toward reconstruction efforts and attempts to mitigate the dislocations of partition. The U.S. military occupation carried out a successful land reform program (see Mitchell 1952 for an account), and in addition assisted with educational reforms that provided virtually universal primary education. Thus, although Korea's stock of manpower and new entrants to the labor force in the late 1940 s were probably less well educated than the Turkish labor force, the educational reforms of the late 1940 s laid a basis for rapid increase in educational attainments in later years.

Spurred by reconstruction activities and an inflow of aid, Korean output grew significantly until June 1950, although it probably did not reattain the levels of the late 1930s. Per capita income figures are not available, but an unweighted index of production, ${ }^{3}$ with 1946 equalling 100 , stood at 171 in 1948 and 149 in 1949 (although items that probably had large weight in the index such as rice, wheat and barley were up only 20 percent over their 1946 levels while items such as nails and chinaware had increased 4 and 8.5 times respectively).

However, whatever gains in output had been achieved by early 1950 were again lost with the outbreak of the Korean war, which lasted until mid1953. During those years, the excess demand generated by wartime expenditures and by the demands of United Nations troops (including Turkish) intensified inflationary pressures. Meanwhile, the initial invasion of large parts of 
South Korea by the north was repulsed by United Nations troops, only to be followed by reinvasion, which was in turn followed by a final repulsion. The fighting destroyed much of the infrastructure that had been rebuilt in the late 1940s. When the war ended in 1953, the South Korean economy was once again severely dislocated.

\subsection{Political and Geopolitical Situations}

It would take this essay too far afield to sketch in any degree of depth the domestic and international political situations of the two countries over the decades after 1953. But a few brief observations are necessary.

First, the perceived threat from the North in Korea led to a degree of cohesion in the Korean body politic that might otherwise have been absent. There was a powerful imperative for economic development that arose not only because of low living standards but also because of rivalry with the North. This phenomenon may have permitted the government to pursue economic goals more single-mindedly than might otherwise have been the case, but it also had its costs: the large defense budget was one such cost. Second, because of these same concerns, Korean foreign policy was firmly based on alliance with the United States. The large aid inflows of the 1950s, and the continued American military presence were consequences. Third, because of memories of the colonial era, Korea did not even have formal relations with Japan until 1965, when a formal treaty was signed, and Japan agreed to extend what were in effect reparations. At least until 1965, proximity to rapidly growing Japan was not a significant plus to Korea's growth, and the Japanese share of Korean trade fell up to 1965.

Although Turkish proximity to the Soviet Union is not the same as the 
Korean partition, Turkey's strategic location nonetheless also determined her international policy stance. Turkey has been a member of NATO and has supported the largest army of any European NATO country, receiving military as well as economic aid from the United States and Western European countries. In terms of both trade and aid, the United States and Western Europe were the dominant economies. Because of proximity as well as a commonality of religion and heritage, there were also strong links to the Middle East.

As to domestic politics, Turkish elections in 1950 brought Adnan Menderes to the Prime Ministership, and turned the Republican Peoples' Party (RPP), the recipient of the Ataturk heritage, out of office. This ended the era of single-party rule in Turkey. Ataturk, who had been a general, had left a strong legacy to the military, which regarded itself as the guardian of the nation and of Ataturk's tradition. Menderes was reelected to office during the 1950 s in an environment that was regarded as increasingly oppressive and, by the late 1950s, there were charges of a rigged election. In 1960, the military intervened, and sponsored the writing of a new constitution which took effect in 1961, when elections were held and a civilian government returned to office (with the RPP winning the 1961 election, and the Justice Party, the successor to the Menderes heritage, winning election in 1965). The military once again intervened in 1971, but again there followed a return to civilian government and democracy under the 1961 constitution. Starting in the mid-1970s, however, there were several years of increasing violence and a deteriorating economy, with excessive and unsustainable borrowing. The government seemed unable to resolve either the economic or the political issues, in part because neither of the two major parties could attain a majority in Parliament and had to enter into a coalition with one of several 
minority parties. In late 1980, the military once more intervened. This time, a new constitution was written, partly with the intention of reducing the influence of the smaller parties, but also with a view to preventing a recurrence of some of the apparent excesses of the 1970s. When elections were held in 1983, the civilian government under Prime Minister Turgut Ozal was operating with somewhat smaller powers than had earlier elected regimes.

Thus, throughout the postwar period, the Turkish military was a major presence in the country's political life. However, for the majority of time, the government was democratically elected under a constitution.

The Republic of Korea was founded in 1948, and Seungman Rhee became President and remained in that office until 1960. The Rhee regime was aptly characterized by Mason, Kim et al.: "Despite the existence of certain trappings of democracy, the Rhee regime was indubitably an authoritarian government..." (Mason, Kim et al:, 1980, p. 44.)

In 1960, a student revolution, with widespread support of other groups, led to Rhee's resignation. A one-year interim government (clearly democratically elected) was unable to maintain law and order, and was overthrown after about a year by a military coup. General Park Chung Hee became chairman of a military council that revised the constitution to permit more centralized government in the expectation that centralization would prevent the apparent excesses of the earlier government; elections were held in late 1963. Although the opposition received 53 percent of the votes, it was badly fragmented and Park was elected President, with his party controlling 110 of 175 seats in the National Assembly. In subsequent elections, Park was returned to office, first with a "landslide victory" in 1967 (Mason, Kim, et al., 1980, p. 51), which effectively endorsed the 
economic success of the regime, but then with lower fractions of the total vote and more charges of voter irregularities. But the major turning point of the political process came after the 1971 Presidential election, in which Park was elected for a third term. In 1972, the Government, apparently alarmed by the reduced margin of victory of popular support, abruptly abolished the existing constitution and introduced a new one in which the procedure for electing the President was converted to an indirect one, thus paving the way for President Park's indefinite stay in power.

Park was assassinated in October 1979, after which there followed an interim period of about a year before General Doo-Hwan Chun became President. His government, which has ruled to the date of writing, has announced that he will serve only one term as President, and held elections for the Assembly in February 1985, which were intended to lead up to an indirect national election in 1988 for determination of President Chun's successor.

Even during the period when President Park's office had clearly been won in a free and open election, all observers would agree that government and power in Korea was highly centralized. And, for periods including the late 1950s, and from the late 1970s to the present, the government has been arguably authoritarian. Its basis of support, however, has been the challenge from the North and its ability to deliver a strong economic performance. Indeed, Mason, Kim et al. concluded that: "As long as the possibility of aggression seemed real to a majority of the population and as long as continued growth assured increased real incomes to both rural and urban communities, the legitimacy of the Park Government in Korea was widely accepted." (Mason, Kim, et al., 1980, p. 56.) 


\subsection{Structure of the Two Economies, Mid-1950s}

By the mid-1950s, the Korean war was over, and the reconstruction effort begun, while the initial period of rapid growth in Turkey had ended and the underlying macroeconomic imbalances were becoming increasingly evident. It is thus useful to contrast the economic structures of the two countries at that time as a starting point for later analysis.

Tables 1, 2, and 3 give an idea of some key magnitudes. The population sizes of the two countries were very similar, each in excess of 20 million (see Table 1). Korea was by far the poorer country. By U.N. estimates, the only Asian countries with lower per capita incomes in those years were India and Burma. Turkey's estimated per capita income of $\$ 210$ was considerably higher than Korea's, although well below that of the richer Latin American countries and lower than any other European country covered by the U.N. estimates at that time. Thus, although both countries were poor, Korean living standards were probably among the lowest in the world, while Turkey was probably at the lower end of the spectrum of "middle income" developing countries.

Table 2 gives some idea of the structure of production in both countries in the mid-1950s. As can be seen, both were predominantly agricultural: in Turkey, 74 percent of the population 1 ives in rural areas, and agricultural output accounted for 41.9 percent of national income originating in agriculture, and 62 percent of the population living in rural areas.

Despite this similarity, there was and is an important difference: Turkey is relatively land-abundant, and Korea is land-scarce. Turkey is favored with a variety of climatic conditions, including: 1) the 
Mediterranean coast where cotton, citrus, tree crops (especially olive trees), and fresh fruit and vegetables vie for rich land; 2) the Anatolean plateau, colder and with somewhat poorer soil, which probably has a comparative advantage in livestock and, to a lesser extent, wheat and other grains; and 3 ) the Black Sea region, where tobacco and hazlenuts are major crops. Turkey's resources are so large that one would expect her to be a net exporter of agricultural commodities throughout the development process: "one foreign visitor aptly suggested that "Turkey should be the California of Europe." In addition to land, Turkey has large deposits of chrome, copper, coal, iron ore and a variety of other minerals. However, there is very little oil, and the country imports its entire supply.

By contrast, Korea had the smallest amount of arable land per capita (and not necessarily good quality land) of any country in the world in the 1950s. Although the country was a net exporter of rice to Japan in the 1930 s, that export reflected the realities of colonial administration; once land reform was undertaken, Korea became a net importer of grains. Korean policy toward agriculture in the 1960 s was one of relative neglect; in the 1970s, policy shifted toward protection for domestic food production, largely on income distribution grounds. Korea is lacking in almost all mineral resources - minerals and oil are major import items.

Table 3 gives data on the structure of expenditures in the two countries in 1955. As can be seen, both had imports considerably in excess of exports; in Turkey's case, foreign aid and other capital flows represented 2-3 percent of GNP in the 1950s. In the Korean case, however, domestic savings were very small, as foreign aid accounted for about 8 percent of GNP, or fourfifths of 1955 investment. ${ }^{4}$ 
Table 4 presents data on the composition of exports and imports in the two countries. As can be seen, Turkey's exports were about 17 times larger in total value than were Korea's. Turkey's exports were predominantly agricultural, with cotton and tobacco the two leading agricultural export commodities. Even so, Turkey's exports of minerals (primarily chrome and copper) were three times as large as Korea's total exports. Other exports, which in Table 4 are recorded as manufactures, constituted no more than 9 percent of total exports. By contrast, Korea's exports were so small that a percentage composition table almost does not make sense. However, what exports there were primarily minerals, with some forestry products and some agricultural and fishery products (especially marine products) constituting the balance.

One final aspect of trade structure deserves at least brief mention. That is, the geographic pattern of trade. Table 5 gives data on the share of trading partners in Korean and Turkish exports and imports. As can be seen, the United States is important for both countries, but much more so for Korea. Reflecting their respective geographies, however, Japan was relatively more important for Korea (although the Japanese share of Korean exports fell by at least half over the subsequent decade) and Europe for Turkey. The large "other" category for Turkey reflects the importance of bilateral trading arrangements (especially with CMEA countries) in Turkey's exports in the mid-1950s.

In sum, there were remarkable similarities between the two countries. They were of approximately equal size in terms of population. Both were heavily agricultural and had low per capita incomes, although Korea's was considerably lower than Turkey's. Both had sizeable military 
expenditure burdens and were recipients of military and economic aid. Both countries had periods of authoritarian rule and periods where the government was legitimized by relatively free elections, although on average the Korean government was considerably more centralized and authoritarian than the Turkish.

There were also significant differences. Turkey had by far the more generous resource endowment, both in terms of land per man in agriculture, and in terms of other natural resources. And Turkey had the period from 1946 onward in which policies could focus at growth and efforts to raise living standards. Korea, by contrast, had been much more devastated by the political aftermath - i.e., partition and departure of the Japanese and the Korean War and was, in the mid-1950s, much less far ahead of the immediate postwar situation than was Turkey.

\section{Economic Policy Regimes}

Turkey's economic performance until 1955 was regarded as one of the most promising of any developing country, while Korea remained a wardevastated country. Over the following 5 years, both countries pursued rather similar economic policies, each with relatively unsatisfactory results. Those policies are the subject of sect. 2.1. In the late 1950s, each embarked upon some needed policy reforms, although the centerpiece of the reform packages and the scope and extent of reforms differed vastly. Those reform packages are the subject of sect. 2.2. In each case, the reform packages set the pattern for the economic policies that were pursued throughout the $1960 \mathrm{~s}$, which are discussed in Sect. 2.3. Section 2.4 then covers the reactions to 
the oil price increase of 1.973, while Section 2.5 traces the shifts in economic policy in each country since 1980 .

\subsection{Policies in the Late 1950s}

Turkish economic policy in the late 1950 s was driven by the difficulties that arose out of the unsustainable and expansionary fiscal and monetary policies that had been pursued in the early 1950s; Korean economic policy was formulated in response to the exigencies of postwar reconstruction against the backdrop of heavy aid dependence. Interestingly, despite the difference in origins, the resulting policies and problems were remarkably similar. The difficulties in each instance manifested themselves in the balance of payments.

As already seen, Korea was heavily dependent on American aid and receipts from American military outlays to cover the import bill. Americans in effect borrowed Korean currency to purchase local goods and services and to provide American troops with domestic currency for local expenditures. At a later date, negotiations were then held covering the exchange rate at which the loan would be repaid in dollars. Inflation was rapid during the war period, when prices as reflected in the cost of living index rose at rates of $167,402,126$, and 53 percent, in the years 1950 through 1953 respectively. 5

Despite that, the Korean authorities attempted to keep the nominal exchange rate constant in the expectation of higher dollar receipts for won loans. By the time the war ended, the exchange rate was thus already heavily overvalued. Frank, Kim and Westphal (p. 32) estimate that, in 1965 constant won per U.S. dollar, the official exchange rate (which had fluctuated between 180 and 250 in 1949) was only 55.6 won per dollar in August 1953 when the 
Korean was ended. Despite periodic devaluations, the real rate fluctuated between a low of 55.7 and 154.8 in the years before 1960 , and did not reattain the 1949 level until the end of 1960. Thereafter, it was always well in excess of 2001965 constant won per dollar.

In response to the pressures that arose on the balance of payments, the authorities took a number of measures: 1) there were multiple exchange rates, with as many as eight different rates for different classes of transactions in the late 1950s; 2) there was extensive exchange control, including licensing of all imports, which were not permitted unless they were on a list of "eligible" commodities; and 3 ) tariffs and surcharges were imposed on those commodities that were imported in an effort to contain excess demand. There were numerous changes in regulations, and the overall exchange regime was chaotic. Despite occasional efforts to provide some relief and incentives to exporters, the discrimination against exports and in favor of the domestic market was enormous. Among the consequences, there was considerable import substitution in consumer-goods industries; in addition, corruption increased among those trying to obtain imports which was a significant factor in the downfall of President Rhee. Needless to say, exports lagged badly as a consequence: even in 1960, Korean exports were only $\$ 33$ million compared to $\$ 40$ million in 1953, representing about 2.4 percent of GNP. 6

Underlying the erosion of the nominal exchange rate, of course, was macroeconomic imbalance. Although annual inflation rates did not again reach 100 percent after 1953, the consumer price index rose more than 20 percent in every year until 1958, and as much as 66 percent in 1955. At that time, these rates were among the highest in the world. 
The origins of inflation lay in the government budget deficit and its financing. As a percent of GNP, the budget deficit rose from 1.9 percent in 1953 to a peak of 7.6 percent in 1955 and remained at about that level until 1958. Once economic policy reforms began, it fell sharply. Budget deficits were financed largely through credit creation, as financial markets were almost nonexistent because of regulation. Nominal interest rates were controlled at very low levels throughout the period, and were negative in real terms until 1958 (see Kim and Roemer, 1979, p. 73).

The growth rate in Korea was lacklustre until 1960, despite the opportunities present in a reconstruction era for rapid growth. In 1960, real GNP is estimated to have been 589 billion won, compared to 422 billion won in 1953 -- an increase of 39 percent, or an average annual rate of less than 5 percent (Bank of Korea, National Income Statistics Yearbook, 1953/57, p. 16). Investment remained at about 10 percent of national income, and foreign aid continued to finance the bulk of investment.

For Turkey, the origins of the macroeconomic difficulties lay in a decision to maintain an exchange rate of TL2.8 per dollar in 1946. This rate was manifestly unrealistic, given the Turkish inflation during the Second World War. But the boom in wheat exports, the ability to run down reserves that had earlier been accumulated, and the availability of Point Four and Marshall Plan aid permitted maintenance of this rate for an extended period of time. When commodity prices fell sharply in 1953, the government reacted by imposing quantitative restrictions on imports -- no importer was to receive permission to import more than a specified percentage of their preceeding year's imports. From the point onward, excess demand for foreign exchange increased as inflation persisted, but was contained through a complex set of 
regulations. ${ }^{7}$ The trade and payments regime became an extremely complex amalgam of multiple exchange rates, with surcharges of different levels of different categories of imports and export premia for specified exports, import licensing, tariffs, bilateral trading arrangements, and export price checks (see Krueger, 1974, Ch. 2 for a description).

There was little conscious "industrialization" policy in Turkey during the $1950 \mathrm{~s}$, but the foreign trade regime nonetheless provided a highly protected domestic market to any domestic supplier of import competing goods. The SEEs and private industry both increased their output fairly rapidly until 1956. Almost all of it was in consumer goods, just as in the Korean case. After 1956, inability to obtain raw materials, intermediate goods, and spare parts severely constrained output of Turkish industry.

Even without inflation, foreign exchange difficulties would have been acute, but there were inflationary pressures arising out of the budgetary deficits incurred as a result of agricultural price supports and large public expenditures on infrastructure. The budgetary deficits were aggravated by the government's effort to suppress inflation by holding down the prices at which SEEs could sell their output. The consequence was large losses by these enterprises, which were financed by Central Bank credits, which further fuelled inflation.

Price controls led to significant discrepancies between official prices and market prices, so that inflation exceeded, and probably substantially so, the rate recorded in official price indices. Even those indices, however, record rates in excess of 20 percent for the years from 1955 to 1957. 


\subsection{Economic Reforms of the Late 1950s and Early 1960s}

In both Korea and Turkey, the economic policy stance of the mid-1950s was unsustainable without a significant change in some key parameters. For Korea, export earnings were stagnant, and growth could proceed only if that situation would change or if foreign aid could be expected to grow indefinitely. The United States had informed the Government of its intention to reduce aid, which made prospects in the absence of policy change even bleaker. Moreover, the government budget was sufficiently imbalanced that the prospect would probably have been for an accelerating rate of inflation even if aid levels had been sustained in the absence of measures to adjust expenditures relative to income. Whereas for the Koreans, it was recognition of the infeasibility of maintaining growth over the long-run which prompted policy reform, for the Turks, reforms were forced upon them by the imperatives of a balance of payments crisis.

Stated another way, in Turkey the option of changing the underlying parameters of economic policy with respect to protection was not considered. The role of state economic enterprises in the economy and the need for control of economic activity was unquestioned, and there does not appear to have been any significant group within Turkey advocating a significant shift in policies of control and regulation. A deep-seated suspicion of private economic activity and belief in the need for detailed regulation and control pervaded Turkish society. While there was opposition to the changes in Korea with dominant businessmen dependent on the restrictive trade regime and controls for their profits, the change in government in 1960 seems to have led to the formation of a consensus on the need for growth-oriented policies and an export orientation. Once begun, President Park's commitment to growth, and 
the highly visible success of the new policies assured the maintenance of the strategy.

In the Turkish case, imports were financed by borrowing from abroad, on ever-worsening terms, until finally even suppliers' credits were unavailable to would-be importers. By the summer of 1958, harvests were left in the fields in the absence of gasoline to power the tractors and the trucks to bring produce to the ports and markets, and many activities were running at far below capacity because of import shortages. Indeed, the situation could be described as having been critical for at least a year before that time, but the Menderes Government resisted policy reforms until it became apparent that there would be no alternative.

The major Turkish policy reforms were carried out under the aegis of an IMF stabilization program in the summer of 1958. The centerpiece was a major realignment of the exchange rate (from TL2.8 per dollar to TL9 per dollar, although the change was implemented through surcharges on imports and subsidies on exports until it was legitimized in the summer of 1960). Other measures included credit and budgetary ceilings, an attempt to rationalize the import regime, and a rescheduling of the debt. In addition, Turkey received a sizeable credit to permit a resumed flow of imports. The intent of the Government, if there was an intention other than to satisfy international creditors enough to be eligibile for resumed lending and foreign aid, was to remedy the short-term macroeconomic imbalances.

Even the rationalization of the import regime took the form of instituting three semi-annual "import programs"; one program listed goods eligible for importation without quantitative restriction (mostly raw materials and intermediate goods used in production where there was no 
domestic source of supply); one program listed quotas for imports of other commodities; yet a third listed commodities that were eligible for importation only under bilateral trading arrangements. Commodities not listed on any of these were not legally importable.

The inauguration of regular import programs, and especially a liberalized 1 ist represented a significant improvement over the chaotic conditions that had prevailed when importers, even with valid licenses, had to queue at the Central Bank for 6 and even 8 months in order to obtain a foreign exchange permit. Nonetheless, the new system permitted the government to liberalize or restrict the trade regime in accordance with the dictates of foreign exchange availability and/or desires to protect domestic industry: shifting of commodities to the quota 1 ist, or removing them from any 1 ist automatically heightened restrictions. And, during the 1960 s, shifts of this sort were a major means by which domestic import substitution was encouraged. The import programs remained the basic instrument of protection for domestic industry throughout the following two decades. Once domestic production of an item had begun, imports of the import-competing good were placed on the "Quota List"; when production was deemed "adequate" to supply the domestic market, the item was removed entirely from the import lists, which meant that it could not legally be imported.

The Korean reforms started in 1957-8 with a first effort at macroeonomic stabilization and the introduction of some export incentives. Thereafter, the process of liberalization continued, and continues to this day. 8 Cutbacks in expenditures permitted a sharp reduction in the rate of monetary expansion, and the rate of inflation plummeted from its 30-50 percent range to virtually zero by 1959. In 1960 (after the Student Revolution), 
reforms of the trade and payments regime began. The initial effort was geared primarly at stimulating exports: the official exchange rate was adjusted (for the first time since 1955) and in addition tax rebates and a number of export subsidies were introduced to compensate for the bias against export activities that would otherwise have resulted from the tariff structure. After 1960, the real exchange rate for exporters was kept relatively constant.

Along with the increased incentives for exporting, the Government through its policy pronouncements assured exporters that those incentives would be maintained. Over the next several years, these assurances were accompanied by a number of policy measures that gave them credibility: 1) The rates of export subsidies and tax incentives were adjusted periodically to insure that exporters did not lose when inflation was not offset by exchange rate changes. 2) Procedures were developed so that exporters could import their needed raw materials and intermediate goods duty-free provided only that they. reexported these materials within a year; indeed, the provisions were sufficiently generous so that there was probably an element of subsidy in the scheme. 3) Exporters were the only ones eligible to receive import licenses and were thus the recipients of whatever premia there were on imports (primarily consumer luxury goods). Finally, 4) exporters were extended highly preferential treatment in receiving credit. Because of interest rate ceilings and credit rationing, the real interest rates applicable were negative, at least until 1965, and the value of credit was substantial.

Thus, the initial set of Korean reforms had two distinct parts: on the one hand, there was a major effort to realign monetary and fiscal policy in order to reduce the rate of inflation drastically; on the other hand, there was a huge shift in incentives away from import substitution and toward export 
promotion.

Turkey and Korea were similar in that 1 ) they both started with trade and payments regimes that were highly protective of import substitution activities and discriminated against exports; 2) they had relatively high rates of inflation (as seen from the perspective of the 1950s and 1960s) and attempted to reduce excess demand; 3) new governments in 1960 were, if anything, more committed to the economic programs and reforms than had been their predecessors.

They differed in three respects: 1) The Turkish reforms were driven by the exigencies of a balance of payments and debt crisis whereas the Korean reforms were motivated largely by a commitment to economic growth through an export-oriented strategy, given that aid flows could not be expected to sustain the sort of growth of imports that would be essential for satisfactory overall economic development. 2) There was no real intent on the part of the Turkish authorities to alter the underlying incentive structure of the economy with regard to exportables and import substitutes. As pronouncements in the First and Second Five-Year Plans amply demonstrate, it was intended to develop industry as a leading sector through import substitution. 3) The Korean Government recognized the role of incentives and was essentially pragmatic in its efforts to stimulate economic performance whereas the Turks remained highly suspicious of private economic activity and remained committed to a policy regime based on direct controls.

\subsection{Policies during the 1960s}

In both Korea and Turkey, policy during the 1960 s and 1970 s really evolved in response to the perceived needs originating from the basic strategy 
that had already been decided upon. In Turkey, perceived needs originated largely in foreign exchange difficulties; in Korea, perceived needs were actions that would support the export drive.

In Turkey, the initial results of the 1958 reforms were highly successful. The stabilization was accompanied by receipt of new credit which financed a resumed flow of imports; partly for this reason, but also because there was a good harvest, the initial response to the stabilization program was a substantial increase in output, combined with a sharp reduction in the rate of inflation (after an initial, once-and-for-all, increase in prices of products of the SEEs). Perhaps because of that, the Menderes government began exceeding the credit and budget ceilings agreed upon with the IMF by late 1959, and signs of inflation reappeared. In May 1960, a military coup removed Menderes from office; interestingly, among the first actions of the new government was to. reinstate the stabilization program.

Throughout the 1960 s, Turkish inflation remained moderate, averaging just under 5 percent annually over the decade. Economic policy was articulated in the First and Second Five-Year Plan, which set industrialization as a major goal, to be achieved through import substitution. Aid in support of Turkey's Development Plans constituted 2-3 percent of GNP during most of the 1960s. The real exchange rate for traditional exports in 1958 prices, which had reached TL7.69 per dollar after the devaluation fell to TL6.82 per dollar in 1963, and to TL5.45 per dollar by 1969. For nontraditional exports, some subsidies were given to offset part of the disincentive inherent in an appreciating real exchange rate, but nonetheless, the real rate in 1958 prices fell from TL9 per dollar in 1958 to TL7.18 in 1965 and to TL6.00 by 1969 (see Krueger, 1974, p. 187). 
Exports responded to the significantly increased incentives which resulted from the more realistic exchange rate in the early 1960s: Turkish exports, which were $\$ 396$ million in 1953 , had fallen to a low of $\$ 247$ million in 1958. They rose by over $\$ 100$ million in 1959 , and reached a level of $\$ 458$ million in 1965 . While this did not represent exceptionally rapid growth, the availability of aid in addition to export earnings led to a fairly comfortable balance of payments position, and the major motive for the import programs in the first half of the 1960 s was to protect domestic industry.

By the mid-1960s, however, the cumulative effect of inflation at rates of 5 percent against the backdrop of stable international prices was beginning to take its toll, and growth of export earnings slowed down markedly. The government attempted to mitigate the situation by providing export incentives, in the form of subsidies, for nontraditional exports, and these grew somewhat more rapidly in the late 1960 s. However, export earnings from the traditional sources of foreign exchange - agricultural and minerals stagnated. Meanwhile, the import content of planned investment and output in import substituting industries generally exceeded expectations, so that demand for foreign exchange was rising rapidly.

With only slow growth in availability and more rapid growth in demand, the import programs became increasingly restrictive in 1966, 1967, and 1968. Nonetheless, foreign exchange difficulties increased, so that by 1969 even those who had received import licenses under an Import Program were waiting 6-8 months before they received their foreign exchange allocation from the Central Bank. In this environment, incentives for producing domestic substitutes of almost anything were very great: no competing imports were permitted; those products dependent on imported raw materials or intermediate 
goods had virtual monopoly positions as their shares of these materials were determined by the import licensing regime. As foreign exchange availability decreased, premia on import licenses rose, and growth rates fell in the late 1960s.

A devaluation in 1970 was aimed at providing more incentives for exports. In the short run, it did so, but the authorities were unable to sterilize the inflow of funds associated with repatriated workers' remittances (who had earlier held their funds abroad) and with reverse capital flight. As a consequence, inflation accelerated rapidly. Thus, despite the fact that exports rose from $\$ 537$ million in 1969 to $\$ 1,317$ million in 1973 , inflation as measured by wholesale prices rose from a rate of 5.6 percent in 1970 to 19.8 percent in 1973.

Whereas Turkish economic policy with regard to the relative incentives for exportable and import-competing.production was driven largely by foreign exchange availability, Korean economic policy in the 1960 s and early 1970s was determined largely by the desire to maintain the momentum of the export drive. Once the export incentives were in place, they were generally altered in order to maintain their constancy in real terms: the real effective exchange rate for exports hardly changed from 1960 to 1968, although the exchange rate itself was pegged in the early 1960 s and floated after 1964, and the fraction of the real rate that originated in export incentives (including tax rebates, export subsidies, and subsidized credit) varied widely. Over time, there was a trend toward greater reliance on the exchange rate, and less on individual incentive schemes, than had earlier been the case. Over time, too, the real effective exchange rate began to be 
adjusted in response to the degree to which export performance was deemed to be flagging or unsustainably rapid.

In support of this general thrust, however, further reforms were undertaken in the 1960s. In 1961, a major overhaul of the protective system was undertaken, as quantitative restrictions were largely replaced by tariffs. In 1964, budgetary reforms consolidated the government accounts and increased fiscal discipline with the result that the inflation rate fell from about 30 percent in 1963 and 1964 to 6 percent in 1965, and remained under 20 percent for the remainder of the 1960s; in the same year, financial reforms resulted in positive real interest rates to depositors for the first time in the postwar period and reduced the degree of subsidy in official lending rates. In 1967, imports were further liberalized, as the earlier positive list of imports was replaced by a negative list (i.e., one that specifically itemized those goods that may not be imported).

As mentioned earlier, American aid was phased out during the $1960 \mathrm{~s}$. Until 1966, Korean policy largely discouraged foreign investment and foreign borrowing. But with decreased aid flows, the government reversed its stance and began to encourage private capital inflows, initially in the form of bank lending. These inflows were carefully controlled, with the government deciding upon the aggregate amount of borrowing that would be permitted and reviewing individual applications for it. After 1970, somewhat greater encouragement was given also to direct foreign investment, although it has remained relatively small contrasted with borrowing.

In all of this effort, however, the export drive was central. Monthly joint meetings of government officials and businessmen were held, chaired by President Park, in which export performance, industry by industry 
was reviewed. In cases where exports appeared to be lagging, inquiry was made as to the difficulties; officials were in many instances then directed to remove restrictions or otherwise facilitate performance. In the Korean system, government officials tried to keep low targets for their industries (because higher targets meant more work for them), and had every incentive to facilitate private economic activity, the opposite of the incentive system in many import substitution regimes, including the Turkish.

No measure of the biases of the two regimes can capture the difference between them, largely because the commitment of the Korean government provided a degree of assurance to exporters that was probably more valuable than some of the incentives that are measurable. Nonetheless, for the study on Foreign Trade Regimes and Economic Development, the bias of the Turkish and Korean regimes was estimated as of the early 1960s: for Korea, it was estimated that in 1966, the relative price of import-competing goods to exportables in the domestic market was .94 times that in the international; in Turkey in 1969, it was about 3.01 times as great.

Moreover, the variation in effective exchange rates and effective rates of protection was much greater in Korea than in Turkey. Table 6 gives some estimates. Although both means and variances are affected by the degree of disaggregation and the coverage of the estimates, the data in Table 6 give an idea of the difference between the Turkish and Korean regime. In many sectors, the incentive for exporting in Korea was greater than the incentive for sale in the domestic market; the opposite was the case only when there were very few exports. Moreover, there was only one sector where the average rate of protection exceeded 80 percent; the next highest was 20 percent, and the range was from a negative 20 percent to a positive 20 percent. In Turkey, 
by contrast, almost all incentives were for production in the internal market; there was probably no sector in which the incentive to export even equalled that to sell domestically. And, as between activities, the range of incentives varied $10-f o l d$, or by 1000 percent, with variances commensurately great.

There can be little doubt, based not only on the data in Table 6 , but also on other evidence, that the Korean incentive structure was much more uniform across activities than was the Turkish, and that the average incentive to export was probably at least as great as that to produce for the domestic market. This contrasts sharply with Turkey's inner-oriented policies.

\subsection{Response to the Oil Price Increase}

As. was mentioned in Sect. 1.3, neither Turkey nor Korea has any significant amount of oil. Consequently, the terms of trade of both countries were seriously affected by the oil price increase of 1973-74, although the prices of Turkey's primary commodity exports rose as a partial offset to the oil price increase. Relative to 1972, Korea experienced a 23 percent deterioration in her terms of trade by 1974 (based on export and import unit values) contrasted with Turkey's 20 percent drop. Because trade was much more important in Korean GNP, the total impact on Korea was much greater than on Turkey.

The policy response of the two countries was quite different. In part because reserves were high and the response to the 1970 devaluation was still improving the balance of payments, the Turkish government did virtually nothing in the short run. By comparison, the Korean reaction was immediate and sharp. In Turkey, the nominal exchange rate was adjusted only with 
significant lags despite the rapid inflation; in 1976, the nominal exchange rate was TL16.67 per dollar as compared with TL14.93 at the end of 1970, although the price level was almost triple its 1970 level. Even after adjusting for inflation in dollar prices, the real price of foreign goods had fallen 40 percent relative to domestic output in the 6-year period.

As inflation was seen to be a major policy problem, the domestic price of energy was restrained. No significant alterations were made in the key parameters confronting the private sector, and public expenditures and the tax structure were not altered. In the absence of any marked policy response to the oil price increase, the initial impact was, therefore, a significant increase in the current account deficit: after a current account surplus of $\$ 660$ million in 1973 , there were deficits of $\$ 561 \mathrm{million}, \$ 1,648 \mathrm{million}$, and $\$ 2,029$ million in the ensuing three years.

The Korean policy response was substantially more complex. The nominal effective exchange rate for exports was increased from 310 won per dollar in 1970 to 398 in 1973 and 484 in 1975. This adjustment more than compensated for the differential between domestic and foreign inflation so that the purchasing power parity effective exchange rate for exports was increased from 308 won per dollar in 1970 to 396 won at the end of 1973; even at the end of 1975, it still stood at 321 won per dollar, a higher real rate than had prevailed at any time in the $1960 \mathrm{s.} 9$ On the import side, the adjustment was even greater; the PPP PLD EER had been 260 in 1970, rose to 332 in 1973 but then fell back to 287 by 1975 .

In addition to raising the real exchange rate, the domestic price of energy was adjusted promptly, with some adjustments in domestic tax rates undertaken to offset the impact on low-income groups. Also, systematic 
efforts were begun to find new sources of foreign exchange earnings, and the Government actively encouraged Korean efforts to develop a market, especially in the Middle East, in construction activities.

Despite these adjustment measures, a large jump in the current account deficit and a sharp increase in inflation were both triggered by the oil price increase. The government was able to increase borrowing in the international private capital market to cover the current account deficit; with that, growth promptly resumed.

The Korean economy suffered a year of relatively slow growth in 1974, but then resumed rapid growth in 1975. Gaining confidence from her ability to withstand the oil price increase but recognizing that the increased oil price would increase the need for earning and saving foreign exchange, policymakers concluded that Korea was ready to enter the "next stage" of development, and undertook measures to start development of "heavy industries", including machine tools, shipbuilding, and an array of other engineering industries.

For Turkey, the period 1976-79 was one of increasing short-term macroeconomic imbalance, as expansionary demand policies resulted in an acceleration of inflation, the balance of payments situation worsened, and the rate of growth diminished, so that per capita income began falling by 1978 . Even without the oil price increase of 1979, the Turkish government would have been unable to sustain its macroeconomic policy stance (including exchange rate policies and the trade regimes as well as fiscal, monetary, and domestic credit policies). There were simultaneously mounting political difficulties, as domestic violence increased, and the Government was unable to come to grips with either the political or the economic problem. 
In January 1980, the Government announced a series of far-reaching reforms, starting with a massive devaluation and an announcement that henceforth there would be frequent adjustments in the exchange rate to keep pace with differentials between domestic and foreign inflation. In addition, prices of outputs of public sector enterprises were increased sufficiently to reduce their deficits and thus sharply cut the size of the public sector deficit.

This general stance of reform, begun under the Demirel government, was continued under the military government headed by General Evren which took power in September 1980. In 1983, however, after some abrupt bankruptcies in the financial markets following very high nominal and real interest rates, the leadership of economic policy was changed, and with it, the fiscal-monetary stance was eased. With the election of late 1983, however, Prime Minister Ozal, who had earlier led the reform effort, resumed the reform program. Quantitative restrictions on imports were virtually eliminated; efforts were made to rationalize, and perhaps even privatize, some of the State Economic Enterprises; and a variety of moves to increase currency convertibility, liberalize the credit market and banking system, and open up the economy were gradually undertaken.

In Korea, the strains placed upon the economy by the expansionary policies pursued to develop develop the heavy engineering and chemical industries were already becoming apparent in 1977 and 1978: the demand for some types of technically-trained personnel rose so rapidly that real wages and salaries for skilled labor tripled within a 3-year period and the differential between wages of skilled and unskilled workers rose substantially; the investment and import costs of the new factories were 
extremely high; partly for that reason and partly for concern about the financial implications to domestic producers who were indebted in foreign currency, the won was not revalued to maintain purchasing power parity with major competitors; and, with a few exceptions (most notably shipbuilding), the new enterprises tended to incur large losses and to operate at small fractions of their intended capacity. Difficulties were compounded by the oil price increase of 1979, and then the political uncertainties that followed the assassination of President Park Chun Hee. By late 1980, the economy was in severe macro imbalance - real GNP growth in that year was minus 6.4 percent. The wholesale price index increased 40 percent from December 1979 to December 1980, the current account deficit jumped to 9 percent of GNP and the rate of gross investment was virtually zero for the last half of the year.

Policies were set in place to address these issues. These included an exchange rate realignment, and also a concerted effort to restore macroeconomic balance. Monetary growth, which had been 27 percent in 1980 , fell to 15 percent in 1983 and 8 percent in 1984; the fiscal deficit simultaneously fell to 1 percent of GNP by 1983. The GNP growth rate returned to the 7 percent range, the deficit on current account had been reduced to 1.7 percent of GNP by 1984, and inflation was down to 2 percent at an annual rate. Thus, both Korea and Turkey entered the early 1980 s with economic problems resulting from past policies as well as the effects of worldwide recession and 1979 oil price increase. In the Korean case, the source of the difficulty was the attempted shift of industrial base toward heavy chemical and engineering industries and the other policies, especially exchange rate, that had been adopted in support of that stance. In Turkey, the problems essentially had their origins in the inner-oriented policies that had been 
pursued for several decades; the oil price increases and other events of the 1970s, had exacerbated the underlying inefficiencies of the economy, but adjustments to those phenomena could not be undertaken independently of addressing the underlying issues.

\section{Contrasts in Performance}

Table 7 provides data on overall economic performance. As can be seen, real GNP in Korea increased six-fold between 1960 and 1984, whereas Turkish GNP rose at about half that rate. Turkish growth in the $1960 \mathrm{~s}$ had been somewhat less rapid than Korea's, but the difference became much more pronounced in the 1970s, and especially the late 1970s.

The differential in per capita incomes rose even more sharply than that of GNP. Although both coutnries had rates of population growth of around 2.9 percent in the late $1950 \mathrm{~s}$, the Turkish rate fell only to 2.5 percent in the late $1960 \mathrm{~s}$ and 2.1 percent in more recent years. By contrast, the Korean population's growth rate had already fallen to around 2 percent by 1970 and to 1.6 percent by the late 1970 s and early 1980s. Whereas Korea and Turkey each had populations of just over 20 million in the early 1950s, the Turkish population is estimated to have been 48.27 million in 1984 , while Korea's was 40.58 million. It will be recalled that estimated per capita incomes (in 1955 prices) were $\$ 70$ and $\$ 210$ for Korea and Turkey respectively in the first half of the 1950s, a differential which increased during that decade. By 1983, per capita incomes in 1983 dollars were estimated to be $\$ 1,240$ for Turkey and $\$ 2,010$ for Korea. Whereas Turkey's estimated per capita income was about three times Korea's in the early 1950s, it was only about 60 percent of Korea's by the early 1980s. While international comparisons of living 
standards are always subject to difficulty, there is little question that Korea was the poorer country in the 1950 s and the more affluent in the 1980 s. This fundamental transformation affected all sectors of the economy. As can be seen from Table 8, agricultural production as well as industrial production rose more rapidly in Korea than in Turkey, although manufacturing was unquestionably the leading growth sector. Interestingly, in both Korea and Turkey, agriculture's share in GNP fell sharply: from 36.5 percent to 13.9 percent between 1960 and 1984 for Korea and from 37.5 to 18.4 percent over the same years for Turkey. But despite the sharper fall in Korea, agricultural production was almost 2.5 times as great in 1985 as in 1960, whereas in Turkey, agricultural production rose a still respectable, but nonetheless substantially smaller, 62 percent. For manufacturing, the structural shift was sharper in Korea; whereas 13.7 percent of GNP originated in manufacturing in 1960, the 1984 figure was 29.2 percent (with an estimated increase in manufacturing output of 1255 percent). In Turkey, the manufacturing share increased from 11.6 to 23.0 percent of GNP, for a total increase of 548 percent. Thus, it was not that manufacturing growth led in one country while agricultural growth led in another: manufacturing rose more rapidly in both countries, but the dominant phenomenon was Korea's faster overall growth.

This faster growth implied, among other things, a much more rapid increase in real wages and urban employment in Korea than in Turkey. Table 9 provides some estimates of the orders of magnitude of the increase. For Korea, real wages had been virtually stagnant in the late $1950 \mathrm{~s}$, and remained so in the early 1960s, although nonfarm employment rose rapidly, from 2.15 million in 1960 to 3.14 million in 1965. After 1965, nonfarm employment 
continued to grow at rates of almost 10 percent annually, but real wages also began rising. By 1970, real wages had risen about 45 percent over their 1960 level. Thereafter, as labor became scarcer, more of the increase in demand for labor was reflected in a rising real wage -- which more than doubled between 1970 and 1980 -- while nonfarm employment grew more slowly, although it almost doubled over the decade.

Data for Turkey are incomplete, but over the entire two decades after 1960, nonfarm employment is estimated to have risen only from 2.8 million to about 5.7 million (compared to 2.1 million to 8.59 million in Korea), and real wages at most rose by about 60 percent. Even then, real wages increases had been caused in part by the political impasses and the power of unions in Turkey to obtain wage increases independently of conditions in the labor market; such increases as there were were at the expense of expanded employment. There is considerable evidence that much of the effort of employers in the late 1970 s was to find ways to automate their factories and reduce their vulnerability to strikes and labor agitation. One of the unfortunate but probably essential parts of the Turkish reforms of the early 1980 s was the decline in real wages that took place.

Rapid growth in Korea was reflected not only in rising real wages and employment opportunities, but also in rising real incomes for all segments of society. Indeed, except for the early 1960 s when the evidence is ambiguous and the period of "heavy industry emphasis" in the late 1970s, the evidence would suggest that the Korean income distribution, which was relatively egalitarian at the beginning of the period, became more so. By contrast, the available evidence would suggest that Turkish income distribution was more unequal in the 1950s, and became even more so with growth. 10 
The biggest contrast is in export performance of the two countries. Data are given in Table 7. In 1960, Korea's exports were on $\$ 33$ million, compared to Turkey's exports of over $\$ 300$ million. By 1984 , Korea's exports were $\$ 29.2$ billion, and Turkey's were $\$ 7.13$ billion. In both cases, the composition of exports had changed; by 1984, almost 94 percent of Korean exports were manufactures, whereas for Turkey the number was 54 percent. And, whereas exports represented only 2.4 percent of Korean GNP in 1960, they were 38.4 percent of Korean GNP in 1984. By contrast, Turkish exports were about 4 percent of GNP in 1960, 6 percent of GNP in 1978, and 10 percent of GNP in 1984. To be sure, the relative importance of imports to the domestic economy had also increased in the Korean case.

Of course, the expansion of manufactured exports in Korea was the main stimulus to industrial growth. Korean industrial production rose 45 fold .over the 23 years after 1960; Turkish industrial production in 1983 was 6.6 times what it had been 23 years earlier. The data in Table 8 show vividly the difference in performance.

Along with Korea's export performance came creditworthiness and her ability to access international capital markets. As Table 10 shows, a major part of the structural transformation in Korea was the rapid rise in the domestic savings rate - from only eight-tenths of one percent of GNP in 1960 to well over 20 percent in the late 1970 s and around 20 percent in the early 1980s. It will be recalled that real interest rates had been negative in the late 1950s; financial reforms in the mid-1960s assured savers of positive real returns on their savings, and the savings rate began rising dramatically.

Even so, it proved highly profitable to attract foreign capital, especially in the late 1960s and early 1970s. As can be seen from Table 10, 
Korea's capital inflows were much more important relative to GNP than were the Turkish - and Korea's were mostly private inflows whereas much of Turkey's was official financing which was negotiated to cover balance of payments difficulties. For Korea, foreign capital augmented domestic savings by as much as 60 percent in the late 1960 s - permitting an investment rate well in excess of 25 percent of GNP while domestic savings rates were still below 20. For Turkey, by contrast, capital flows have remained 2-3 percent of GNP, and Turkish investment, which was initially a much higher fraction of GNP than was Korean, has not exceeded 20 percent.

It should be noted, however, that the difference in savings performance has been far smaller than the difference in growth rates - the greater difference has been the efficiency with which investment was allocated and employed.

There is also an interesting contrast on the macroeconomic front. As the last two columns of Table 10 show, until the 1970s, Korea's inflation rate generally exceeded the Turkish. Both countries experienced accelerating inflation right after the 1973 and 1979 oil price increases, although Turkey was in any event undergoing a period of accelerating inflation during the latter part of the 1970s. After 1980, it was a major objective of policy in both countries to bring inflation under control, although in the Turkish case, this objective was combined with that of opening up the economy. As the numbers in Table 10 show, Turkey continued to experience double-digit inflation rates, with rates of around 50 percent in 1984 and 1985 . By contrast, in Korea the rate of inflation is estimated to have fallen to less than 1 percent annually in 1984 and 1985. 


\section{Conclusions and Postscript}

There are too many factors at work influencing economic performance in any given country, or any pair of countries, for analysis to permit ironclad conclusions. Nonetheless, the contrast between Korea and Turkey is striking. By almost any measure, Turkey was the more affluent country in the 1950s, and better positioned for economic development. Her natural resources were far superior; her initial savings rate and level of per capita income was higher; and her record of growth during the 1950 s appeared exceptionally good. Korea in the $1950 \mathrm{~s}$ was unable to grow rapidly despite the opportunities for above-average growth that usually arise in the aftermath of a war. Her savings rate was exceptionally low, and her export performance was very bad. The country's per capita endowment of natural resources was also poor.

Insofar as there are either economic advantages or economic disadvantages to a military alliance with the United States, both countries had them. And, insofar as proximity to a rapidly growing region of the world affects growth, Turkey and Korea had Europe and Japan, respectively.

Both countries in the 1950 s were subject to macroeconomic imbalances and rates of inflation that were then regarded as very high by world standards. Both adopted reforms in the late 1950 s and early 1960s. In the Korean reforms, the trade regime was central, and shifting its orientation was the lasting achievement of the period. Inflation did decelerate, and shifts in the government budget and rising real interest rates encouraged domestic savings. These were significant shifts, but the centerpiece was the shift in toward an outer-oriented trade regime. Korean analysts suggest that there was a fair degree of unanimity in the view that Korea could no longer depend on 
aid and that there was no choice but to make the outer-orientation work. While U.S. aid officials and others participated in the discussions and decisions (and may have been instrumental in convincing policymakers that there was a feasible alternative), the decisions of the late 1950 s appear from all accounts to have been Korean decisions.

By contrast, by mid-1958 the Turkish government recognized that the economic situation was unsustainable, but only in the sense that economic activity was severely disrupted because import flows had virtually ceased. Reforms were adopted only reluctantly and only because there appeared to be no other way to reschedule debt and to provide for a resumed flow of imports that was deemed essential to halt the decline in economic activity.

While rationalization of the chaotic trade regime that had preceeded the August 1958 program was clearly an objective of policy, there was no intention whatsoever to open up the economy, or to abandon the traditional suspicion of private economic activity. Partly because there was little faith in the efficacy of incentives, and partly because of the belief indirect controls, the aims were purely for macroeconomic balance. There was no intention to alter the balance of incentives between exportable and importcompeting production. While Turkey was, during the 1960s, probably more successful in maintaining price stability than was Korea, the degree of protection accorded to domestic firms increased and Turkey became, if anything, more inner-oriented with the passage of time.

If there are any central lessons from the contrast of Korea and Turkey, they are probably two. First, the prevailing economic structure of a country can never be taken as a given; it must be seen in light of the 
economic incentives that arise from the policy environment and condition peoples' behavior. Secondly, there is an important difference between "liberalization" efforts where the sole intent is to remove some of the bias against exports that existed in the last phase of a balance-of-payments crisis and a reform effort aimed at fundamentally altering the bias of the trade regime.

In this regard, it is important to note that there were significant mistakes made by Korean policy makers. It is not that economic policy in one country was "right", and the other "wrong". If there was a difference in policy formulation itself, it rather lay in the speed with which policymakers recognized their mistakes and dealt with them. By the early 1980s, all members of the Korean economics community were agreed that the effort to promote heavy industry had been a mistake; there were incipient debt-servicing difficulties in 1969 and on several later occasions. The problems were rapidly identified in each instance, and efforts were then made to insure that the same mistakes would not be repeated. Likewise, Korean performance has not been without its drawbacks: import liberalization has proceeded only slowly and reluctantly, and financial liberalization is still far from completed.

Turkey's economic difficulties were clearly apparent to all observers in 1957, in 1969, and by 1976. Yet in each instance, the fact that the economy was inner-oriented permitted policymakers to persist in "patch-up" efforts rather than to address their fundamental problems. In one sense, the outer-orientation of the Korean trade regime must be given the fundamental credit for the more satisfactory Korean performance than the Turkish. At a deeper level, however, it might be argued that it was the Korean policymakers' willingness to confront their problems and to recognize difficulties early which, on one hand, led to the decision for an outer-oriented trade strategy, 
and on the other hand, led them to address perceived difficulties more quickly, and perhaps more importantly more fundamentlally, than did the Turkish policymakers.

Turkey's effort at a shift to a more outward-orientation began in the winter of 1980. Even then, quantitative restrictions were not removed, and the major shift was through the guarantee to maintain a more realistic exchange rate. Although those in authority clearly recognized the need for a fundamental change in economic policy, there were many influential Turks, in and out of government, who did not accept the changes.

Nonetheless, the commitment to an outer oriented regime has continued to the time of writing. Against the background of worldwide recession, Turkey has liberalized quantitative restrictions substantially, and maintained real incentives for exporters. Export performance in consequence has been impressive, with exports (which stood at only $\$ 2.9$ billion in 1980) rising to $\$ 7.1$ billion in 1984. Performance has been impressive enough to persuade many Turks that the earlier suspicion of private economic activity may have been overdone.

While the commitment to an outer oriented regime has been much less firm than was the Korean two decades earlier, there has been enough success to provide some momentum for its continuation. Whether initial successes with the shift will have resulted in enough of a shift in Turkish thinking, or whether the next shift in political power will reverse the liberalization achieved so far, remains to be seen.

The centrality of trade policy in both Korea and Turkey is beyond dispute. The experience of these two countries vividly demonstrates the central importance of trade policy, and the importance of analyses of the sort pioneered by Max Corden, in affecting countries' economic well being. 
Table 1. Comparative Data on the Rorean and Turkish Economies, 1952-4

\begin{tabular}{|c|c|c|c|}
\hline & $\frac{\text { Population }}{\text { (million) }}$ & $\frac{\text { NNP }}{\text { (US\$ million) }}$ & $\frac{\text { Per Capita Income }}{(\text { dollars })}$ \\
\hline Korea & 21.38 & 1,500 & 70 \\
\hline Turkey & 22.46 & 4,717 & 210 \\
\hline
\end{tabular}

SOURCE: United Nations, Per Capita National Product of Fifty-Five Countries: 1952-54, Statistical Series E, No. 4, New York.

Table 2. Structure of Output, Rorea and Turkey 1955

(percentage of GNP)

Korea

44.8

11.2

3.0

41.0

Turkey

41.9

$14.2^{a}$

5.8

38.1

a Includes all industry.

SOURCES: Korea: Bank of Korea, National Income Statistics Yearbook, 1953-67, Seoul, 1968.

Turkey: State Planning Organization, First Five Year Plan, 19631967, Ankara 1964, p. 13. 
Table 3. Structure of Expenditures, Turkey and Rorea 1955 (percentage of GNP)

\begin{tabular}{|c|c|c|c|c|c|}
\hline & Consumption & Investment & $\begin{array}{l}\text { Government } \\
\text { Consumption }\end{array}$ & Exports & Imports \\
\hline Korea & 86.4 & 12.3 & 8.7 & 1.6 & 9.8 \\
\hline Turkey & 74.0 & 14.0 & 15.0 & 4.3 & 6.6 \\
\hline
\end{tabular}

SOURCE: Krueger, p. 12 and Korea, Bank of Korea, National Income Statistics Yearbook, 1953-1967, p. 10

Table 4. Composition of Exports, Rorea and Turkey $1955^{1}$

$\begin{array}{cccc}\begin{array}{c}\text { Total } \\ \text { Exports }\end{array} & \begin{array}{l}\text { Agricultural } \\ \text { Exports }\end{array} & \begin{array}{l}\text { Mineral } \\ \text { (Smil.) }\end{array} & \text { (percentage of total exports) }\end{array}$

$\begin{array}{lrrrr}\text { Korea } & 17.6 & 23.4 & 51.6 & 25.0 \\ \text { Turkey }^{2} & 305.0 & 75.3 & 15.7 & 9.0\end{array}$

SOURCES: Korea: Wontack Hong, Factor Supply..., Table A.11 and A.12 Turkey: Krueger, p. 182 .

Notes: 1 The commodity classification may not be identical for the two countries.

2 Turkish data are for 1956. 
Table 5. Geographic Distribution of Exports and Imports, 1955 (percentages)

\begin{tabular}{rrrrr}
\multicolumn{2}{c}{ Korea } & & \multicolumn{2}{c}{ Turkey } \\
Exports & Imports & & Exports & Imports \\
\cline { 5 - 5 } 31.9 & 34.9 & & 15.5 & 22.4 \\
39.1 & 14.7 & & 0.3 & 0.7 \\
0.7 & 19.7 & & 43.1 & 38.1 \\
- & 2.1 & & 5.3 & 5.8 \\
- & - & 5.8 & 6.7 \\
18.3 & 28.6 & 30.0 & 26.3
\end{tabular}

SOURCE: United Nations, Yearbook of International Trade Statistics, 1955. 
Table 6. Estimated Incentive Levels in Rorea and Turkey, 1968

a. Korea. Effective Subsidy Rates

(percent)

\begin{tabular}{|c|c|c|c|}
\hline & For export & $\begin{array}{c}\text { For Domestic } \\
\text { Industry } \\
\end{array}$ & Averag \\
\hline $\begin{array}{l}\text { Agriculture, forestry and } \\
\quad \text { fabrics } \\
\text { Processed food } \\
\text { Beverages and tobacco } \\
\text { Mining and energy } \\
\text { Construction materials } \\
\text { Intermediate products I } \\
\text { Intermediate products II } \\
\text { Nondurable consumer goods } \\
\text { Consumer durables } \\
\text { Machinery } \\
\text { Transport equipment }\end{array}$ & $\begin{array}{r}-9.4 \\
1.8 \\
12.6 \\
2.7 \\
4.4 \\
26.0 \\
11.6 \\
4.1 \\
1.5 \\
1.9 \\
-5.6\end{array}$ & $\begin{array}{r}21.7 \\
-19.6 \\
-20.8 \\
4.5 \\
-12.9 \\
-21.9 \\
13.1 \\
-15.7 \\
23.6 \\
21.0 \\
80.8\end{array}$ & $\begin{array}{r}21.3 \\
-18.0 \\
-19.5 \\
4.1 \\
-12.1 \\
-15.7 \\
13.0 \\
-11.2 \\
19.5 \\
20.2 \\
80.3\end{array}$ \\
\hline
\end{tabular}

b. Turkey Domestic Resource Costs (TL per dollar)

\begin{tabular}{|c|c|c|c|c|c|}
\hline - & Mean & Variance & & Mean & Variance \\
\hline $\begin{array}{l}\text { Food \& beverages } \\
\text { Textiles } \\
\text { Forest products } \\
\text { Leather products } \\
\text { Paper products } \\
\text { Rubber products } \\
\text { Plastic products }\end{array}$ & $\begin{array}{l}14.11 \\
13.48 \\
10.44 \\
10.24 \\
23.69 \\
45.59 \\
37.05\end{array}$ & $\begin{array}{r}46.06 \\
43.77 \\
\text { n.a. } \\
\text { n.a. } \\
67.40 \\
890.49 \\
843.90\end{array}$ & $\begin{array}{l}\text { Chemicals } \\
\text { Cement } \\
\text { Glass \& ceramics } \\
\text { Iron \& steel } \\
\text { Iron \& steel products } \\
\text { Other metal products } \\
\text { Machinery \& parts } \\
\text { Transport equipment }\end{array}$ & $\begin{array}{l}14.56 \\
14.80 \\
10.80 \\
13.68 \\
93.87 \\
14.17 \\
21.81 \\
27.78\end{array}$ & $\begin{array}{r}16.92 \\
6.26 \\
28.35 \\
29.70 \\
43,737.12 \\
22.89 \\
139.31 \\
278.88\end{array}$ \\
\hline
\end{tabular}
SOURCES: a. Frank, Kim, and Westphal, Table 10-3. Subsidies were computed
the Corden treatment of home goods.

b. Krueger, 1974, Table VIII-1. 
Table 7. Indicators of Economic Performance Korea and Turkey, 1960-1984

\begin{tabular}{|c|c|c|c|c|c|c|}
\hline \multirow[b]{3}{*}{$\begin{array}{l}1961 \\
1962 \\
1963 \\
1964 \\
1965\end{array}$} & \multicolumn{2}{|c|}{ Real GNP } & \multicolumn{2}{|c|}{$\begin{array}{l}\text { Per Capita } \\
\text { Income }\end{array}$} & \multicolumn{2}{|c|}{ Exports } \\
\hline & $\frac{\overline{\text { Korea }}}{(196}$ & $\frac{\text { Turkey }}{100)}$ & $\frac{\text { Korea }}{\text { (196 }}$ & $\frac{\overline{\text { Turkey }}}{100)}$ & $\frac{\text { Korea }}{(\$}$ & Billion) \\
\hline & $\begin{array}{l}105.6 \\
107.9 \\
117.7 \\
129.0 \\
136.5\end{array}$ & $\begin{array}{l}102.0 \\
108.3 \\
118.8 \\
123.6 \\
127.5\end{array}$ & $\begin{array}{l}102.6 \\
101.9 \\
108.1 \\
115.1 \\
119.0\end{array}$ & $\begin{array}{r}99.4 \\
102.9 \\
110.2 \\
111.9 \\
111.8\end{array}$ & $\begin{array}{l}.041 \\
.055 \\
.087 \\
.119 \\
.175\end{array}$ & $\begin{array}{l}.347 \\
.381 \\
.368 \\
.411 \\
.464\end{array}$ \\
\hline $\begin{array}{l}1966 \\
1967 \\
1968 \\
1969 \\
1970\end{array}$ & $\begin{array}{l}153.9 \\
164.1 \\
182.6 \\
207.7 \\
223.6\end{array}$ & $\begin{array}{l}142.8 \\
148.8 \\
158.7 \\
167.3 \\
177.0\end{array}$ & $\begin{array}{l}131.2 \\
134.5 \\
146.2 \\
162.7 \\
171.3\end{array}$ & $\begin{array}{l}122.7 \\
125.3 \\
130.0 \\
133.7 \\
137.9\end{array}$ & $\begin{array}{l}.250 \\
.320 \\
.455 \\
.622 \\
.835\end{array}$ & $\begin{array}{r}.491 \\
.522 \\
.496 \\
.537 \\
.588\end{array}$ \\
\hline $\begin{array}{l}1971 \\
1972 \\
1973 \\
1974 \\
1975\end{array}$ & $\begin{array}{l}243.1 \\
257.0 \\
293.4 \\
315.9 \\
337.8\end{array}$ & $\begin{array}{l}194.9 \\
209.5 \\
220.8 \\
237.1 \\
255.9\end{array}$ & $\begin{array}{l}182.7 \\
189.5 \\
212.5 \\
224.9 \\
236.5\end{array}$ & $\begin{array}{l}148.1 \\
155.2 \\
159.5 \\
167.1 \\
175.6\end{array}$ & $\begin{array}{l}1.068 \\
1.624 \\
3.225 \\
4.460 \\
5.081\end{array}$ & $\begin{array}{r}.677 \\
.885 \\
1.317 \\
1.532 \\
1.401\end{array}$ \\
\hline $\begin{array}{l}1976 \\
1977 \\
1978 \\
1979 \\
1980 \\
1981 \\
1982 \\
1983 \\
1984\end{array}$ & $\begin{array}{l}385.5 \\
434.5 \\
476.7 \\
507.7 \\
481.3 \\
511.1 \\
539.9 \\
592.2 \\
636.2\end{array}$ & $\begin{array}{l}275.6 \\
294.9 \\
286.5 \\
293.9 \\
290.9 \\
302.8 \\
316.5 \\
327.2 \\
346.7\end{array}$ & $\begin{array}{l}265.6 \\
294.8 \\
318.5 \\
321.0 \\
311.9 \\
326.0 \\
339.1 \\
365.7 \\
387.6\end{array}$ & $\begin{array}{l}185.3 \\
194.3 \\
184.9 \\
185.8 \\
180.0 \\
181.8 \\
188.0 \\
190.0 \\
201.3\end{array}$ & $\begin{array}{r}7.715 \\
10.047 \\
12.711 \\
15.055 \\
17.505 \\
21.254 \\
21.873 \\
24.445 \\
29.244\end{array}$ & $\begin{array}{l}1.960 \\
1.753 \\
2.288 \\
2.261 \\
2.910 \\
4.703 \\
5.746 \\
5.728 \\
7.134\end{array}$ \\
\hline
\end{tabular}

SOURCE: International Monetary Fund, International Financial Statistics, 1985 Yearbook and Per Capita Income. 
Table 8. Indices of Agricultural and Manufacturing Production, 1960-1984

$(1960=100)$

\begin{tabular}{|c|c|c|c|c|}
\hline & $\frac{\text { Agricultural }}{\text { Korea }}$ & $\begin{array}{l}\text { Production } \\
\text { Turkey }\end{array}$ & $\frac{\text { Industrial }}{\text { Korea }}$ & $\begin{array}{c}\text { Production } \\
\text { Turkey }\end{array}$ \\
\hline $\begin{array}{l}1961 \\
1962 \\
1963 \\
1964 \\
1965\end{array}$ & $\begin{array}{l}110 \\
102 \\
112 \\
132 \\
134\end{array}$ & $\begin{array}{l}102 \\
106 \\
110 \\
117 \\
110\end{array}$ & $\begin{array}{r}105 \\
139 \\
158 \\
170 \\
180\end{array}$ & $\begin{array}{l}105 \\
106 \\
122 \\
159 \\
176\end{array}$ \\
\hline $\begin{array}{l}1966 \\
1967 \\
1968 \\
1969 \\
1970\end{array}$ & $\begin{array}{l}144 \\
136 \\
138 \\
158 \\
156\end{array}$ & $\begin{array}{l}125 \\
127 \\
134 \\
134 \\
139\end{array}$ & $\begin{array}{l}226 \\
292 \\
397 \\
479 \\
535\end{array}$ & $\begin{array}{l}215 \\
238 \\
266 \\
298 \\
305\end{array}$ \\
\hline $\begin{array}{l}1971 \\
1972 \\
1973 \\
1974 \\
1975\end{array}$ & $\begin{array}{l}160 \\
166 \\
170 \\
178 \\
202\end{array}$ & $\begin{array}{l}149 \\
153 \\
142 \\
158 \\
169\end{array}$ & $\begin{array}{r}623 \\
724 \\
982 \\
1268 \\
1515\end{array}$ & $\begin{array}{l}337 \\
373 \\
434 \\
468 \\
506\end{array}$ \\
\hline $\begin{array}{l}1976 \\
1977 \\
1978 \\
1979 \\
1980 \\
1981 \\
1982 \\
1983 \\
1984\end{array}$ & $\begin{array}{l}220 \\
236 \\
252 \\
258 \\
210 \\
232 \\
238 \\
240 \\
250\end{array}$ & $\begin{array}{l}181 \\
183 \\
186 \\
190 \\
192 \\
195 \\
203 \\
203 \\
208\end{array}$ & $\begin{array}{l}1997 \\
2405 \\
2976 \\
3335 \\
3271 \\
3709 \\
3882 \\
4500 \\
\text { n.a. }\end{array}$ & $\begin{array}{r}556 \\
601 \\
616 \\
584 \\
554 \\
599 \\
628 \\
662 \\
\text { n.a. }\end{array}$ \\
\hline
\end{tabular}

SOURCES: World Bank EPD databank. For Korea, statistics from Bank of Korea National Income, supplemented by IBRD Economic Report, various issues; Turkey - data from State Planning Organization. 
Table 9. Real Wages and Rmployment, 1957-1984

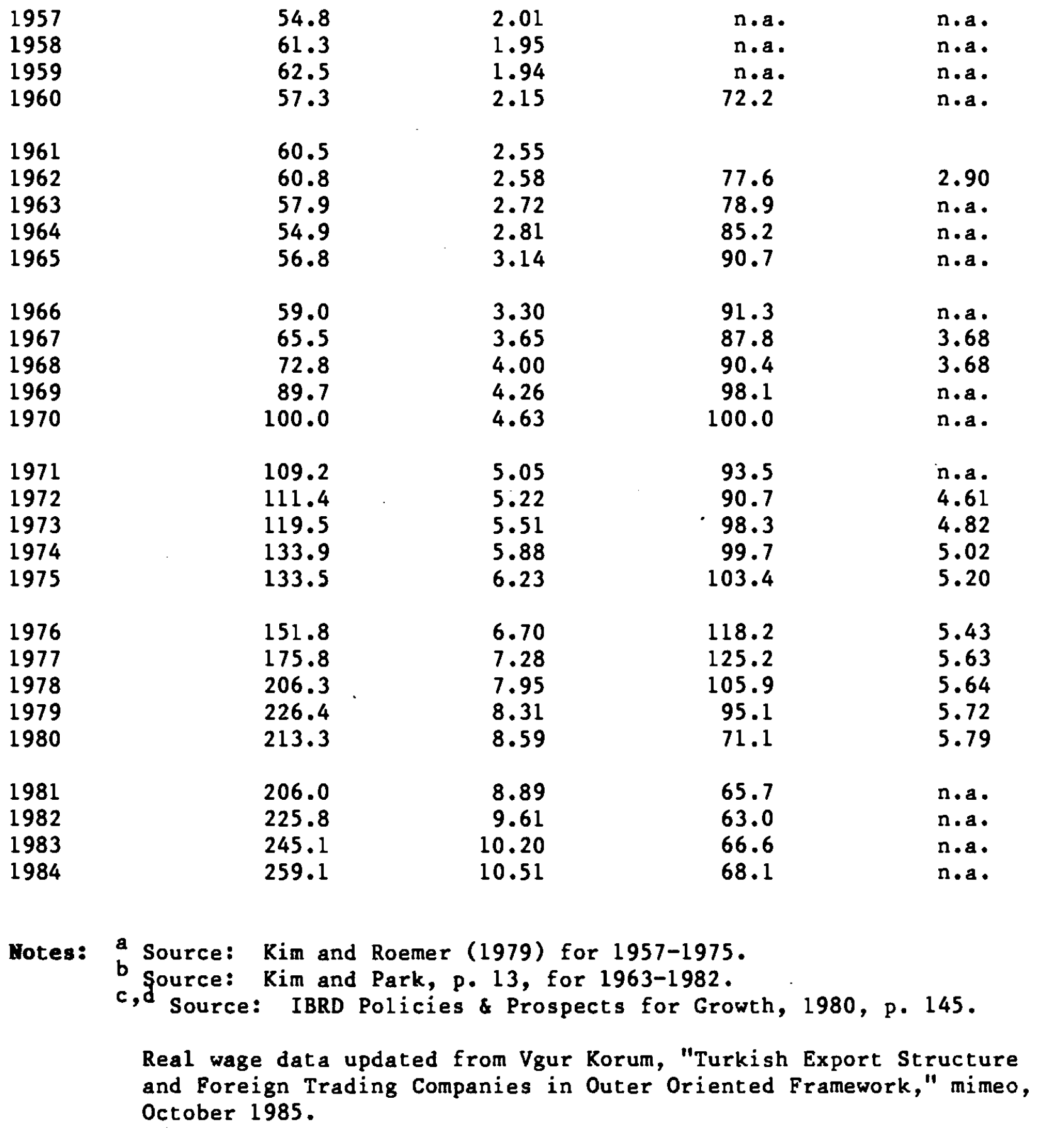

Turkey

$\begin{array}{cc}\text { Roal wages } & \text { Nonfarm } \\ \frac{\text { Real }}{1970=100} & \frac{\text { Employment }}{\text { (millions }}^{\text {(milon }}\end{array}$

$\frac{\text { Turkey }}{\frac{\text { Real wages }}{1970=100}^{c} \frac{\begin{array}{c}\text { Nonagricultural } \\ \text { Employment }\end{array}}{\text { (millions) }}}$

\section{7 \\ 1958 \\ 1959 \\ 1960 \\ 1961 \\ 1962 \\ 1963 \\ 1964 \\ 1966 \\ 1967 \\ 1968 \\ 1969 \\ 1971 \\ 1972 \\ 1974 \\ 1976 \\ 1977 \\ 1978 \\ 1979 \\ 1981 \\ 1982 \\ 1983 \\ 1984}

\subsection{1 \\ 1.94}

2.55

2.81

3.65

4.00

4.26

5.05

5.22

5.51

5.88

7.95

8.31

8.89

9.61

10.20

10.51

\begin{abstract}
n.a.
n.a.

n.a.
\end{abstract}

77.6

78.9

85.2

91.3

87.8

98.1

00.0

93.5

90.7

98.3

99.7

118.2

125.2

05.9

95.1

65.7

63.0

66.6

n.a.

n.a.

n.a.

5.63

5.64

5.72

5.79
October 1985. 
Table 10. Savings Investment, Capital Flows, and Inflation, 1960-1984

\section{Domestic Gross Savings Korea Turkey}

1960

1961

1962

1963

1964

1965

1966

1967

1968

1969

1970

1971

1972

1973

1974

1975

1976

1977

1978

1979

1980

1981

1982

1983

1984
$.8 \quad 13.7$

2.9

3.3

8.7

8.7

12.9

11.6

11.1

13.6

\section{4}

11.8

11.4

15.1

18.8

\section{4}

15.8

16.5

16.0

15.9

17.3

15.4

15.7

23.5

20.5

\section{8}

13.6

16.4

15.7

14.4

18.6

23.1

.25 .1

26.4

26.6

19.9

19.6

21.5

26.9

30.1
Gross $\frac{\text { Investment }}{\text { Korea } \frac{\text { Turkey }}{\text { (as } \% \text { of }} \frac{\text { Capital Inflow }}{\text { KNP) }} \text { Turkey }}$

10.9

13.2

12.8

18.1

$14.0 \quad 15.3$

15.0

21.6

21.9

25.9

28.8

26.8

25.2

21.7

25.6

31.0

29.4

25.5

27.3

31.1

35.4

31.5

28.4

26.2

27.8

30.0
16.1

15.8

15.3

15.4

14.9

17.6

17.3

18.0

17.5

19.5

17.3

20.1

18.1

20.7

$\begin{array}{rr}8.6 & 0.5 \\ 8.6 & 0.4 \\ 10.7 & 2.0 \\ 10.4 & 1.6 \\ 6.9 & 1.6\end{array}$

6.4

8.4

8.8

11.2

10.6

1.3

1.1

1.0

1.4

1.8

$\begin{array}{rr}9.3 & 2.3 \\ 10.7 & 2.1 \\ 5.2 & 4.3 \\ 3.8 & -1.1 \\ 12.4 & 0.6\end{array}$

22.5

24.7

25.0

18.5

18.3

21.4

21.5

20.3

20.7

20.1

$$
10.4
$$

2.4

0.6

3.3

7.6

10.2

7.9

4.8

3.1

3.5
3.7

6.3

7.0

4.0

0.9

3.5

2.0

2.2

2.7

2.4
Inflation Rate

Korea Turkey

$\begin{array}{rr}10.7 & 5.3 \\ 13.2 & 2.9 \\ 9.4 & 5.7 \\ 20.6 & 4.2 \\ 34.6 & 4.4\end{array}$

$10.0 \quad 8.9$

$8.9 \quad 4.4$

$6.4 \quad 5.1$

$8.1 \quad 3.4$

6.86 .0

$$
9.2 \quad 5.6
$$

$8.6 \quad 17.0$

$13.8 \quad 18.4$

$6.9 \quad 19.8$

$42.1 \quad 29.7$

$26.6 \quad 11.0$

$12.1 \quad 16.0$

$9.0 \quad 23.5$

$11.6 \quad 50.1$

$18.8 \quad 64.8$

$38.9 \quad 107.8$

$20.4 \quad 37.5$

$4.7 \quad 25.8$

.230 .4

$.7 \quad 51.6$

SOURCES: Korean savings, investment and capital inflow: Kim Kwang Suk and Park JoonKyung, Table 2-7.

Korean and Turkish prices: International Monetary Fund, International Financial Statistics Yearbook, 1985, pp.100-1

Turkey Gross Domestic Investment and Savings: State Planning Organization, Turkey; Capital Inflow: International Monetary Fund, International Financial Statistics Yearbook, 1985, PP. 628-629. 


\section{NOTES}

1 See Lewis (1968) for a history.

2 It is doubtful if the conversion of land from forests and grazing land to wheat was economic in the long run. See Hirsch and Hirsch, 1963.

3 Frank, Kim, and Westphal, 1975, p. 9.

4 It is unclear how military expenditures and military imports enter into the national income accounts in either country. Korea has continued, throughout the period of rapid development, to devote sizeable resources to military expenditures. However, Turkey as a member of NATO has also had a large military budget and received military aid. It seems likely that the drain of resources into military expenditures in the two countries was fairly comparable, and that this constitutes a similarity, rather than a difference, between them.

5. Data from International Monetary Fund, International Financial Statistics, Supplement to $1966 / 67$ issues, Korea page.

6 This result was not unintended. The object of the Rhee Government had been to maximize aid inflows, and. "balance of payments needs" were used as a lever in aid negotiations. See Cole and Lyman, 1971.

7 Despite the measures, a sizeable black market developed and trade statistics of that period undoubtedly understate the actual value of trade.

8 Once the export drive was under way, exporters were permitted to import any item used in production for export duty-free. The percentage of imports subject to any quantitative restriction fell sharply in the early $1960 \mathrm{~s}$, but in 1967 still stood at 39.6 percent, although these 
restrictions did not apply to exporters. The ratio fell gradually thereafter, reaching 15.2 percent by 1984. See Nam, 1985, Table 3.

9 Source: Wontack Hong, "Export Promotion and Employment Growth in South Korea," Table 8.6, in Krueger, Lary, et al. All PPP PLD EER estimates are in constant 1965 won prices.

10 All estimates of income distribution are fraught with difficulty. For 1973, it is estimated that the bottom 20 percent of the Turkish income distribution received 3.5 percent of all income, while the top 20 percent received 56.5 percent. For Korea, the corresponding 1976 estimates are 5.7 percent and 45.3 percent. See World Bank, World Development Report, 1985, Table 28 . 
REFERENCES

Cole, David C. and Lyman, Princeton, 1971. Korean Development, The Interplay of Politics and Economics, Harvard University Press, Cambridge.

Frank, Charles R. Jr., Kim, Kwang Suk, and Westphal, Larry E., 1975. Foreign Trade Regimes and Economic Development: South Korea, Columbia University Press for the National Bureau of Economic Research, New York. Hirsch, Eva and Hirsch, Abraham, 1963. "Changes in Agricultural Output Per Capita of Rural Population in Turkey, 1927-60", Economic Development and Cultural Change, July.

Hong, Wontack, 1981. "Export Promotion and Employment Growth in South Korea", in Anne 0. Krueger, Hal B. Lary, Terry Monson and Narongchai Akrasanee, eds., Trade and Employment in Developing Countries: 1. Individual Studies, University of Chicago Press, Chicago.

Hale, William, 1981. The Political and Economic Development of Modern Turkey, St. Martin's Press, New York.

Kim, Kihwan, 1985. The Korean Economy, Korea Development Institute, Seoul. Kim, Kwang-suk and Roemer, Michael, 1979. Growth and Structural Transformation, Harvard University Press, Cambridge, MA.

Kim, Kwang-suk and Park, Joon-Kyung, 1985. Sources of Economic Growth in Korea: 1963-1982. Korea Development Institute, Seoul. Krueger, Anne 0., 1974. Foreign Trade Regimes and Economic Development: Turkey, Columbia University Press for the National Bureau of Economic Research, New York. 
Lewis, Bernard, 1968. The Emergence of Modern Turkey, Oxford University Press London .

Mason, Edward S., Kim, Mahn Je, Perkins, Dwight H., Kim, Swang Suk, and Cole, David C., 1980. The Economic and Social Modernization of the Republic of Korea. Harvard University Press, Cambridge, Massachusetts.

Mitche11, Clyde, 1952. "Land Reform in Asia, A Case Study," National Planning Association, Pamphlet No. 78, Washington, D.C.

Nam, Chong Hyun, 1985. "Trade Policy and Economic Development in Korea", Discussion Paper No. 9, Korea University, Seoul. 
</ref_section> 